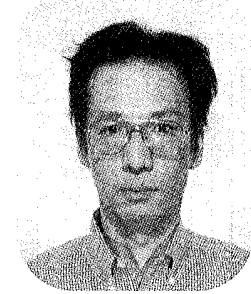

\section{本田 康裕}

Yasuhiro HONDA

○1954年9月生末れ

1972年早稲田大学理工学部卒業，1980年早稲田大学大 学院工学研究科博士後期課程修了, 現在国士舘大学工 学部機械工学科教授

○研究・尃門テーマはは自動車エンジンの振動騒音低減に 関する研究

正員, 国土舘大学工学部

（ 1 154-8515 東京都世田谷区世田谷4-28-1

E-mail : honda@kokushikan.ac.jp)

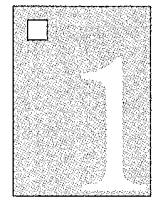

はじめに

ここ数年，投稿研究論文の作成はワードプロセッサ（以 下，ワープロ）が主流になっている。作成した原稿ファイ ルも，インターネットの普及で郵送ではなく，学会のホー ムページを利用してアップロードされることが増え，学会 とのやりとりが簡便化されている。

現在のワープロソフトといえば，マイクロソフト社の $\lceil$ Microsoft Word」（以下，Word）と「一太郎」が有名だ ろうが，論文作成ではWordのほうが一太郎よりもシェア が大きい，と聞いている。この理由としていくつかの原因 が考光られるが，

-Windows 95の発売以来, Wordの高機能化として使い勝 手が向上

・英語版のWordを使用すれば，操作性など基本的な使い 勝手を変えることなく，国際学会へのファイルでの投稿 ややりとりが可能

• OS (Windows95, 98, NT, 2000) と同じメーカのため, バージョンアップによる新機能の付加が早い

などがあげられかと思う。しかし，最近Adobe社製の Acrobatを使用することにより，多くのアプリケーション ソフトで作成したファイルをPDF (Portable Document Format）ファイルにすれば，国内外の学会で論文が投稿で きるようになってきている。攵の意味では，Word，一太 郎に投稿上の差がなくなりつつあるといえよう。

論文投稿にあたっては，文章，数式，表，図などが学会 の替定書式に従え机ばよく，Wordと闰じように，一太郎 も刘応できる。このため，投稿論文作成における一太郎の 使い方の一例を述べたい。ただし，ユーザが一太郎のどの バージョンを使用しているかわからないので，一太郎 Ver.5以降を刘象に紹介したい。

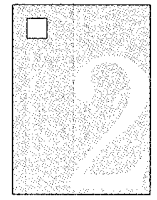

\section{学会規定の書式への対応}

現行の一太郎は，バージョン10で，ワードと同じような

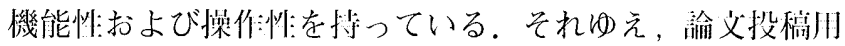


書式の設定は，

・テンプレート（定型文書のひな形）の利用

- 差込の利用

によって行うことができる。テンプレートの利用のほうが 簡単だが，古いバージョンの一太郎では無理があるので， ここでは, 後者の差込の利用を考えたい，差込とは，郵送 物の宛名書きに多用されることが多い方法で，

・あらかじめ位置決め，文字に関する情報（使用するフォ ントの種類，大きさ）を組み込んだ文面ファイルの用意 ・流し込むテキストのみの別ファイルの用意

の 2 種類のファイルを組み合わせるのである。例えば，配 布先が複数ある場合にひとつひとつの宛名ごとに書式を合 わせることが面倒である。この場合，住所，氏名，郵便番 号などの書式（位置，行数，フォントの種類，大きさ）を 決めたファイル，すなわち文面ファイルを作成し，これに 複数の宛名で構成されるファイル（テキストだけで作成） を流し込む。これが差込である。この場合，文面ファイル をまず起動しておく必要がある。

これを使用して，ユーザ（論文投稿者）側が，宛名に相 当するあらかじめ作成した論文の原稿（テキストのみ）フ アイルを学会側で用意したファイルに流し込むのである。 この方法では，文書の位置決めのみで，肩文字の文字装飾 などはユーザ側でしていただくしかないことをあらかじめ お断りしておく.

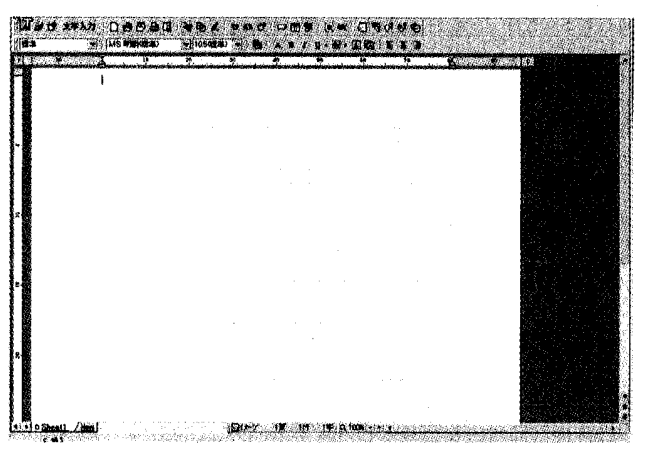

図 1 一太郎10の起動画面

\begin{tabular}{|c|c|}
\hline 捕人 & \\
\hline 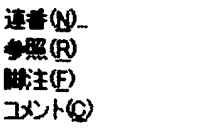 & ! \\
\hline 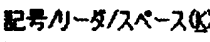 & • \\
\hline 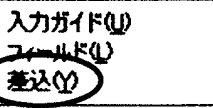 & ! \\
\hline 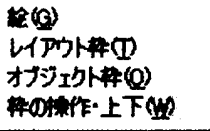 & ! \\
\hline 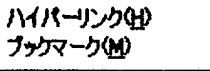 & ! \\
\hline 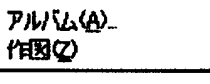 & Shift+F7, \\
\hline
\end{tabular}

\begin{tabular}{|c|c|}
\hline \multicolumn{2}{|l|}{ 青 式 } \\
\hline 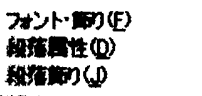 & \\
\hline 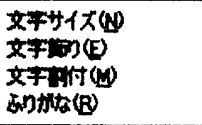 & \\
\hline 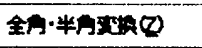 & \\
\hline 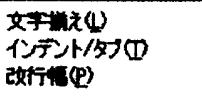 & \\
\hline 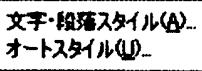 & Cotron \\
\hline 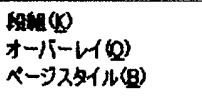 & : \\
\hline 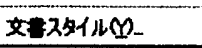 & $F 9$ \\
\hline
\end{tabular}

図 3 一太郎の基本メニュー（その2）

\section{2-1 投稿論文の見出し}

まず，一太郎を起動すると，図 1 に示す画面になる。 起動した画面には，罒 1 の最上段に示される文書名の下に 基本メニューがある，左よりファイル，編集，表示，挿入， 書式，けい線，ナビ，ツール，ウィンドウ，ヘルプである. ナビがWordにはないメニューである。これは，ユーザ用 の整理機能というべきものである。その他は表現こそ違え， Wordと同様のコマンド群である，論文作成で多用される メニューは，罒 2 から 4 に示すように，ファイル，編集， 挿入，書式，ツール，けい線であろう。特に使用頻度の高 いコマンドはすでに, デフォルトでアイコン化されている. いずれもWordのユーザでもそれほど違和感なく使用でき るのではないだろうか.

さらに，ツールボックスがあり，ユーザで表示設定でき る。これも，標準から始まり，作図，けい線に至るまで10 種類以上に及ぶが, 枠操作, 書式ぐらいの表示を勧める.

\section{2-2 差込の読み込み}

読み込むファイルは，学会の執筆要綱に従った書式が設 定された文書ファイルである。この文書には，あらかじめ タイトル，著者名打よび所属，概要（和文，英文)，キーワ 一ド，本文などのテキスト枠を所定の位置に配置してある。 作成した文書を起動後に，基本メニュ一の挿入 $\rightarrow$ 差这 $\rightarrow$
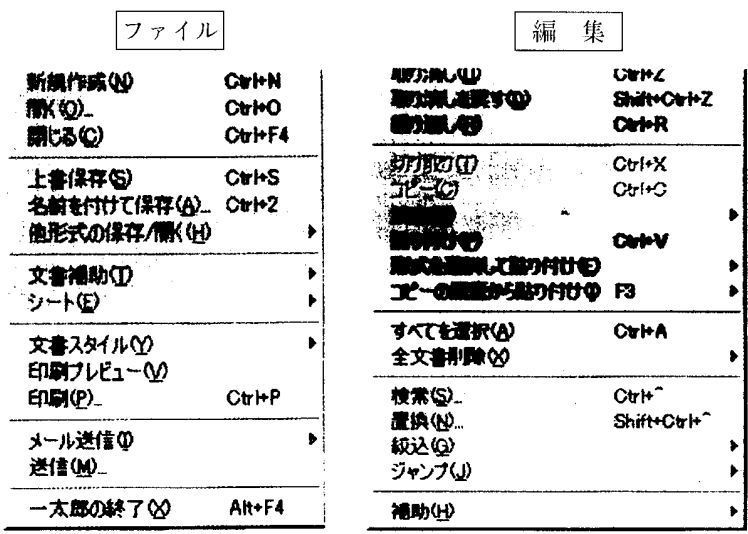

図 2 一太郎の基本メニュー（その1）
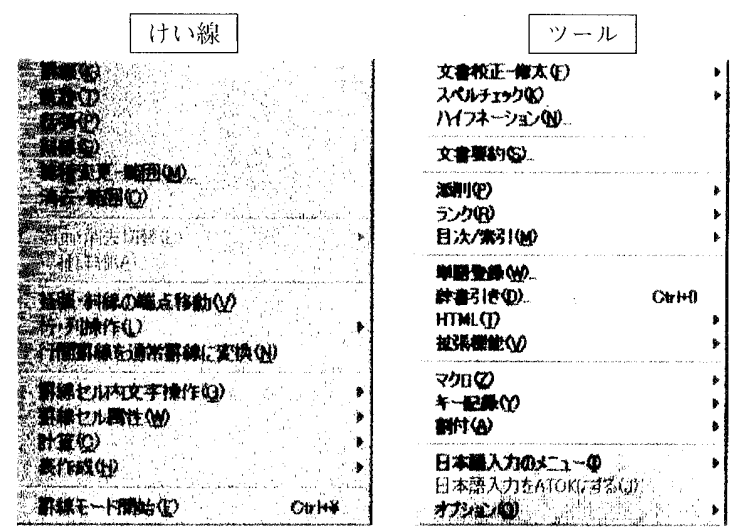

図 4 一太郎の基本メニュー（その3） 


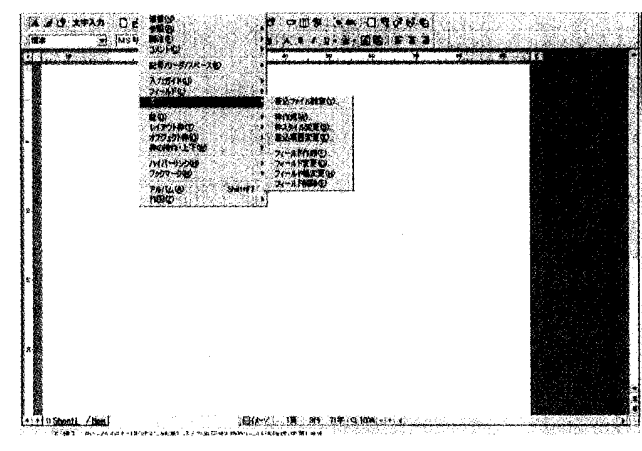

図 5 一太郎10の差込コマンド

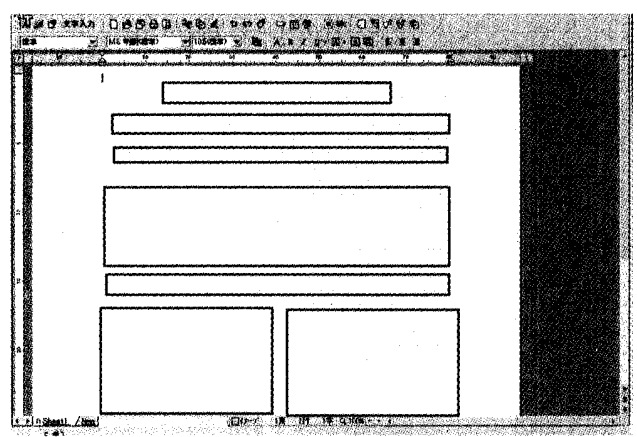

図 6 一太郎10の差込画面（1ページ目，一部合成）

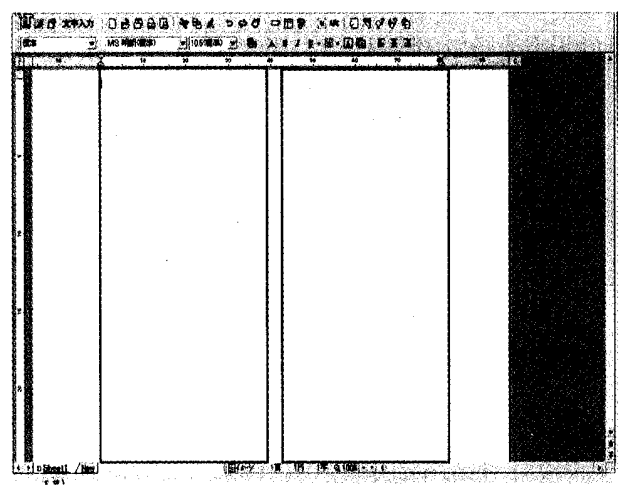

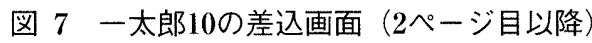

差込ファイルの設定を選択すれば，読み出すファイルの選 択になる。これを通常の読み込みをすればよい，見ため はただの空白のページだが，テキスト枠には，項目 1 , 項 目2の表記が入る。これが差込用書式になる。な拉, 差込 のコマンドは図 5 に示すとおりで，テキストデータの差込 は, 図 6 打よび 7 に 1 ページ目，2ページ目以降の差込 楛を示している。ただ，この罒は，流し込むテキストの 割り付け位置をわかりやすいように一部合成してある。

作成する原稿は，学会の執筆要項に従って，上述のよう に，タイトル，サブタイトルという順序で作成する。その さい,タイトルとサブタイトルの間には改行を行っておく 必要がある。すなわち, 項目ごとに差し込むデー夕を改行

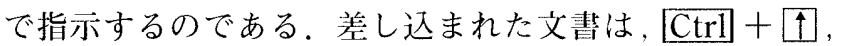
Ctrl 1 †で表示できる.

このように，表題や著者名などは基本的に文学だけでま ず構成されるが，文字どおりテキストだけなので，文字装 飾や他の機能を与えるのは, 次の段階である。結局, 表題 などの位置が差入書式で決まっていれば，後は比較的容易 な作業である。

\section{2-3 文字装飾他について}

文字飾りが必要な㕍文字や化学記号の特殊文字の作成に は手間のかかる作業ではあるが，さほど難しい操作ではな い、テキスト流し込み時に，文字装飾ができれば簡単だが， 本稿では, 文字の大きさやフォントの指定, 文字:の唒置程 度に留めて扎きたい。この場合には，而倒ながら，テキス 卜流し込み後，文字䬣りや特姝加「ををていただくしかな

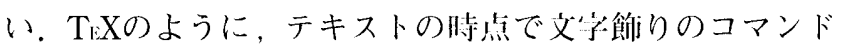
を用いて挟め机ばよいが，一太郎ユーザにとっては後で述 ベる文它飾りのほうが簡䏚であろう。
英文の概要やキーワードは，スペルチエックを利用すれ ば，少なくともつづりの間違いが減る。

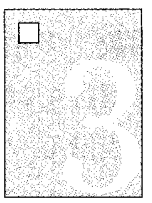

本文の作成

タイトル，著者名，概要，キーワードなどが差込機能を 利用して位置決めされれば，文字装飾，レイアウトを決め ればよいが，本文も同様に行える。

まず，表題などを記述後，本文もその後に続けて記述し ておく.このさい, 数式, 罒表などは, 後回しにしておく. この段階で本支は，テキストのみである，注意すべきこと は，見出しなど改行が必要なところはテキスト入力時に必 ず入力して扰くことである。そうしないと，切れ目のない 文字の羅列になってしまう。テキスト流し込み後でも修正 はできるが，できるだけテキスト入力時にできることをや っておくことをすすめる。

次に, 見出しや章番号は, スタイル機能, 段落機能を利 用すればよい，ただし，インデントについては事前に設定 しておく必要がある。

数式は，比較的古いバージョンでは，アドインソフトの 使用で作成可能であるが，比較的新しいバージョンでは， $\mathrm{J} \mathrm{S}$ 数式作成を利用すればよく，挿入䇠所は作成前後で指 示すればよい，表は，一太郎上で作成でき，簡単な計算な ら作成した表で可能である。専用の作表ソフトには，マイ クロソフト社のエクセル，ロータス，そして云四郎がある。 作闵は，Wordであれ，一太郎であれ，簡単な四であれば ワープロはてで叮能である。しかし，拉のずから限界もあり， やはり，ユーザ闻の使い慣れたグラフィックソフトでの

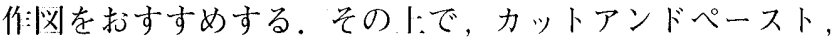


コピーアンドペーストでの図の切り貼りをすべきであろ う。このときの注意点は, 図のグループ化を必ずして抢く ということである，これをしていないと，図周辺が変更さ れるような場合に，図が分解してしまうことがある。一太 郎10で読み込める画像ファイルは，BMP， GIF，JPEG， $\mathrm{WMF}, \mathrm{EMF}$ 形式をもつファイルである。このファイを 読み込むさいは，切り抜きパターンも指定できる。この画 像枠は四つの基準があり，ユーザの目的にあわせて使用す ることを勧める。

1. 固定

これは，ページ内で枠を固定し，周囲の文字が変わ っても同じ位置を維持する。

2. 行

画像枠が指定した行に貼り付く．指定行の移動に従 って,この枠も動く。

3 . 行中央

2 と同じですが, 指定した行の中央に絶えず貼り付く.

4. 文字

行の代わりに指定した文字に貼り付くが，化学記号 などには便利かもしれない.

グラフも同様であり，表計算ソフトでの作成が可能であ るが, やはり，グラフ専用作成ソフトの利用をすすめる。 特に表計算ソフトを利用してのグラフ作成ではプロット間 を結ぶ線の問題がある。結線には，スプライン関数や多項 式近似などを利用することは可能であるが，それだけでは 作者の意図が反映できるか疑問である，たまに，表計算ソ フトで作成したと思われるグラフを見かけるが，作者の意 図が反映できるグラフ作成が今後の課題であろう。

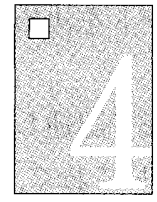

\section{その他の機能}

\section{4-1 参考文献について}

肩文字で参考文献や著者の所属の番号付けをするが，己 れも最近の一太郎では，脚注機能で行うことができる．脚 注は，基本メニューの挿入 $\rightarrow$ 脚注 $\rightarrow$ 作成を選択して行 う。通常では，脚注はそのページに作成される．脚注エリ アはページごとのページ末か, 文書末の設定ができるので, ここでは，文書末を選択する。

\section{4-2 オートスタイル}

これまで，差込の利用について述べてきたが，最近の一 太郎は，テキスト入力後オートスタイル機能を利用して， 見栄えのする文書が作れる。しかし，これは，デフォルト では学会の書式にあっていないため，変更するする必要が ある、段落スタイルやフォント，文字の大きさなど注意を 必要とする。この場合には，段落スタイルを用いれば．括 して変更可能である。

以トのように，最新のバージョンだけでなく，現行で使 川されているであろうバージョンまでを含め, 棆文投稿を
前提として一太郎の機能の一部を紹介したが, Windows上 での一太郎は，決してWordに対して劣っているわけでは ない，日本語ワープロの代表格として進歩してきた利点が Word以上にある。しかし，国内外の学会への対応を考え ると，Wordになってしまうのだろう。しかし，ここ数年 来, 前述のようにPDFファイルでの原稿提出が可能になっ てきたのであれば，国内でしか対応できないと思われてき た一太郎で作成したファイルも十分使用可能である。

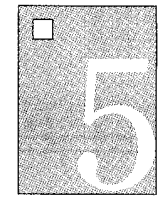

\section{Macintoshで一太郎}

Apple社のマッキントッシュ対応の一太郎は，筆者が知 る限り現在バージョン 5 である。このバージョンは, 1995 年以来そのままのようである。マッキントッシュの一太郎 はWindowsのそれの起動画面とは趣を異にしているが， $\operatorname{MacOS}$ 利点を生かして当時としては十分な機能を有し ていたしかし，現在ではその差はなく，Windowsの一太 郎のほうが上まわっているといえる。

論文作成においては，前述のように差込機能を利用すれ ばよいが，数式やグラフ作成のためには，表計算ソフトや 数式作成ソフトは別に用意する必要があることが, 現在の Windows版の一太郎に対して遅れている部分であろう。筆 者は，数式にはDesign Science社のMath Typeを, グラフ には日本ポラロイド社のDelta Graphを利用している. Windows版のように総合ソフト化されればよいが， Windows版がこれだけ普及していると難しいのであろう。

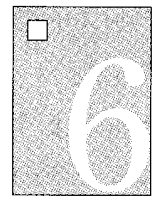

おわりに

一太郎での論文作成について，差込機能を中心に述べて きたが，現行の一太郎を使用すれば，Wizard化や他の新た な機能を利用すれば，さらに簡便な書式作成が可能と考え る。特にマクロに対応できるバージョンで使用されている 一太郎ユーザが圧倒的に多いなら, 機会をみて提案したい. また，Adobe社製のAcrobatでの対応ができれば，論文投 稿者は本学会のみならず国外学会などへの投稿が一太郎と 併用して可能になる．Acrobatを用いて，PDF化するため のPDF WriterとDistiller（またはAcrobat Exchange）の使 い分けについても，機会があれば述べたい。

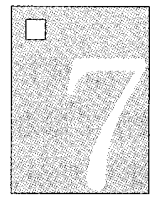

\section{参考書籍}

一大郎の使用法に関しては，さまざまな書籍が出版され ている、執筆にあたって筆者が参考した書籍を 1 冊あげて おく.

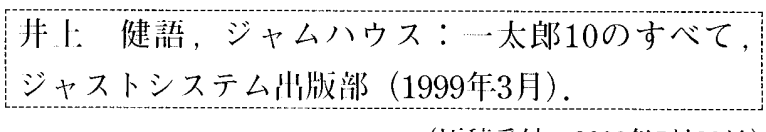

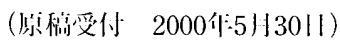

